\title{
Deep Learning, Hydrological Processes and Uniqueness of Place
}

Keith Beven ${ }^{1}$

${ }^{1}$ Lancaster University

May 11, 2020

\section{Hosted file}

Deep Learning and the Uniqueness of Place.pdf available at https://authorea.com/users/319874/ articles/449564-deep-learning-hydrological-processes-and-uniqueness-of-place 